\title{
Not eating alone: Andean bear time patterns and potential social scavenging behaviors
}

\author{
Angela Parra-Romero ${ }^{1}$, Robinson Galindo-Tarazona ${ }^{1}$, José F. González-Maya ${ }^{2,3}$ and I. Mauricio Vela-Vargas ${ }^{2,4 *}$ \\ 1 Parque Nacional Natural Chingaza, Parques Nacionales Naturales de Colombia, Calle 7411 -81, Bogotá, Colombia. angieparra10@ \\ gmail.com (APR), robinson.galindo@parquesnacionales.gov.co (RGT). \\ 2 Proyecto de Conservación de Aguas y Tierras, ProCAT Colombia/Internacional, Calle 97a. 10-67, Of. 201, Bogotá, Colombia. \\ jfgonzalezmaya@gmail.com (JFGM) \\ ${ }^{3}$ Instituto de Ecología, Universidad Nacional Autónoma de México, Circuito Exterior s/n, Ciudad Universitaria, Ciudad de México, \\ México. \\ ${ }^{4}$ Wildlife and Fisheries Science, School of Natural Resources and the Environment, University of Arizona, Environment \& Natural \\ Resources 2, 1064 E Lowell Street, 85721, Tucson, Arizona, USA. : imvelavargas@email.arizona.edu (IMVV) \\ *Corresponding Author.
}

Human-Andean bear (Tremarctos ornatus) conflicts are increasing due to the establishment of livestock or crops near to its natural habitats. Here we report scavenging time patterns of Andean bears and the potential social scavenging behaviors in Choachí and Guasca municipalities, Cundinamarca department, buffer zone of Chingaza National Natural Park, Colombia. Between 2013 -2015, we obtained 31 Andean bear scavenging events, allegedly related with human-bear conflict reports; most records occurred in Choachí municipality ( $n=29)$. Daily scavenging behaviors showed a heterogeneous pattern, where bears prefer to scavenge in morning hours (6:00 h-10:00 h) with small activity in the afternoon (15:00 h-17:00 h). Furthermore, we report on the first potential record of social activity of three adults scavenging on the same carcass at the same time with no aggressive/antagonistic behaviors between the individuals. Most aspects of Andean bear wild behaviors are still unknown; our observations represent interesting additions to the natural history of the species that could also be included in future programs for the mitigation and reduction of conflicts with human communities in the Andean region of Colombia.

Los conflictos Humano - Oso Andino (Tremarctos ornatus) han incrementado debido al establecimiento de sistemas ganaderos o de agricultura cercanos a sus hábitats naturales. Reportamos los patrones temporales de carroñeo de Osos Andinos y comportamientos potenciales de carroñeo social en los municipios de Choachí y Guasca, departamento de Cundinamarca, zona de amortiguamiento del Parque Nacional Natural Chingaza, Colombia. Entre los años 2013-2015, registramos 31 eventos de carroñeo por Oso Andino, reportados como eventos de conflicto Humano - Oso. La mayoría de los eventos ocurrieron en el municipio de Choachí $(\mathrm{n}=29)$. Los comportamientos diarios de consumo de carroña mostraron un patrón heterogéneo, donde los osos prefieren carroñar en horas de la mañana (6:00 h -10:00 h) con poca actividad durante las horas de la tarde (15:00 h - 17:00 h). Además, reportamos el primer registro potencial de comportamientos sociales de tres adultos, carroñando en el mismo cadáver a la misma hora, sin presentar comportamientos de agresividad / antagonismo entre los tres individuos. El conocimiento de los comportamientos de oso Andino en vida silvestre aún es incipiente o desconocido. Nuestras observaciones aportan al conocimiento de la historia natural de la especie, los cuales podrían ser incluidos en futuros programas para la mitigación y reducción de los conflictos con comunidades humanas en la zona andina de Colombia.

Key words: Andean Range; chingaza Massif; cundinamarca; scavenging; social behavior; spectacled bears; Tremarctos ornatus.

C 2019 Asociación Mexicana de Mastozoología, www.mastozoologiamexicana.org

\section{Introduction}

Andean bear (Tremarctos ornatus) is one of the largest carnivore species in the American continent; endemic to the tropical Andes, and the only representative of the Ursidae family in South America (García-Rangel 2012). Lack of substantial ecological information on the species has been one of the main obstacles for constructing long-term conservation and management plans, despite being an emblematic species for most Andean countries and protected areas (Peyton et al. 1998; Kattan et al. 2004, Vela-Vargas et al. 2011; García-Rangel 2012). Andean bears are being negatively affected by different threats including natural habitat transformation, mostly derived from productive activities expansion (e.g. livestock production and agriculture), and illegal hunting (Orejuela and Jorgenson 1999; Armenteras et al. 2003; Vela-Vargas et al. 2011). The establishment of livestock or crops near to Andean bear habitats has considerable contributed to the emergence of conflicts between the species and farmers whom has invested significant economic resources in those activities (Goldstein et al. 2006).

Andean bears are predominantly herbivores; their diet is mostly composed of bromeliads and palms (e. g., Puya spp., Greigia spp., Geonoma spp.), and some fruits such as Macleania rupestris (Uva Camarona) and Esperomeles goudoutiana (Mortiño) depending on seasonal availability (Troya et al. 2004), however, individuals can also consume animal protein either from predation or scavenging (Goldstein et al. 2006; Rodriguez et al. 2014; Gonzales et al. 2016). In general adults feed solitarily with scarce records of different adults feeding simultaneously and instead maintaining considerable separation distance between individuals (Castellanos et al. 2005, Goldstein et al. 2006). 
Andean bears are known as facultative scavengers: they can predate live animals and consume death animals opportunistically (Wilson and Wolkovich 2011; GarcíaRangel 2012), and currently the prevalence of scavenging over predation is debated (Jorgenson and Sandoval 2005; Goldstein et al. 2006; Figueroa 2015). Scavenging behavior records are scarce in literature and normally such records are related with predation and no with opportunistic scavenging events (Figueroa 2015), as it has for other bear species (e. g., brown bears, Ursus arctos; Elgmork and Tjorve 1995, Quinn and Buck 2000), where records include small groups of individuals actively searching for dead fish in small creeks without presenting antagonistic behaviors among individuals.

This note aims to describe Andean bears scavenging time patterns and documents that the species might potentially adopt social none-antagonistic behaviors when food availability is concentrated and abundant, as occurs in other bear species. The observations presented herein contribute to the scientific study of Andean bear natural history, enhancing ecological behavioral patterns knowledge potentially applicable to the conservation of this endangered species.

\section{Materials and Methods}

Study area. Chingaza National Natural Park (Ch-NNP) is located on the Eastern range of the Colombian Andes (Cordillera Oriental) between $4^{\circ} 20^{\prime}, 4^{\circ} 50^{\prime} \mathrm{N}$ and $-73^{\circ} 30^{\prime},-73^{\circ} 55^{\prime}$ W. Ch-NPP elevation ranges from 800 to 4,020 masl. and covers an area of 76,000 ha. Main habitats present in the area include Andean forest and paramo ecosystems distributed between Cundinamarca and Meta departments (e.g., states; Parques Nacionales Naturales de Colombia 2016). The field observations presented in this contribution were obtained in Choachí and Guasca municipalities which cover areas both inside and outside Ch-NNP.

Data collection. From 2013 to 2015, field surveys were carried out by park rangers in areas where Human-Andean bear interactions events occurred in Andean forest and Paramo on the Ch-NNP buffer zones located in Choachí and Guasca municipalities. When a predation report was informed by the community, park rangers verified the level of decomposition of the domestic animal carcass. If fresh, rangers identified if the predator was a bear or other species such Puma concolor or even feral dog groups (Canis lupus familiaris; Márquez and Goldstein 2014). For the cases in which the carcasses presented a high degree of decomposition, camera traps (Reconyx $\odot$, Wisconsin, USA) were installed to detect individuals that consumed the carcass, to obtain any information regarding the event. Exact location, animal consumed, date, time and the animal's owner name were also recorded to generate a database of events. Each camera was installed during ten days after each conflict event in the area were the domestic animal were reported by local ranchers. All bear pictures were analyzed to estimate the age of the individuals and were validated by Andean bear experts from multiple countries.
Data Analysis. Every record of bears scavenging in front of the camera were considered an independent event; consecutive records over one-hour time-lapses were considered as one capture (Castaño-Uribe et al. 2013, GonzálezMaya et al. 2015). All the records were organized in an hourly-based day-cycle (24 h), in order to evaluate bear scavenging time patterns throughout the day. We used circular statistical analysis to evaluate the uniformity on the distribution of frequencies of the records and identified the activity scavenging patterns of Andean bears (Di Bitteti et al. 2006, González-Maya et al. 2015, Cáceres-Martínez et al. 2016, Zapata-Rios and Branch 2018). Kuiper test for homogeneity were estimated using package Circular for R in $\mathrm{R}$ studio version 1.0.153 (R Core Team 2017).

\section{Results}

A total of 31 scavenging records were obtained during field assessments from dead domestic animals reported by local ranchers. All the scavenging events were related with dead domestic animals (e. g., cows) found dead by local communities and reported to Ch-NNP Rangers. Choachí municipality was the locality with the highest number of scavenging events recorded $(n=29)$; in Guasca municipality only two scavenging events were recorded.

We found four events in which more than one individual were scavenging, while 27 events recorded only one individual. In cases were more than one individual were scavenging on a carcass, the average time for each event was 24 minutes, while when solitary bears were recorded, scavenging time was lower (14 minutes). The longest recorded event occurred when three adult bears were scavenging at the same time ( 45 minutes).

Scavenging activity showed a heterogeneous pattern for Andean Bears along 24-hour day period $(K=3.1498, P$ $<0.01)$. Bears showed preference for diurnal scavenging activities, especially during morning hours (6:00 $\mathrm{h}$ to 10:00 h) with $77.4 \%$ of the events (Figure 1).

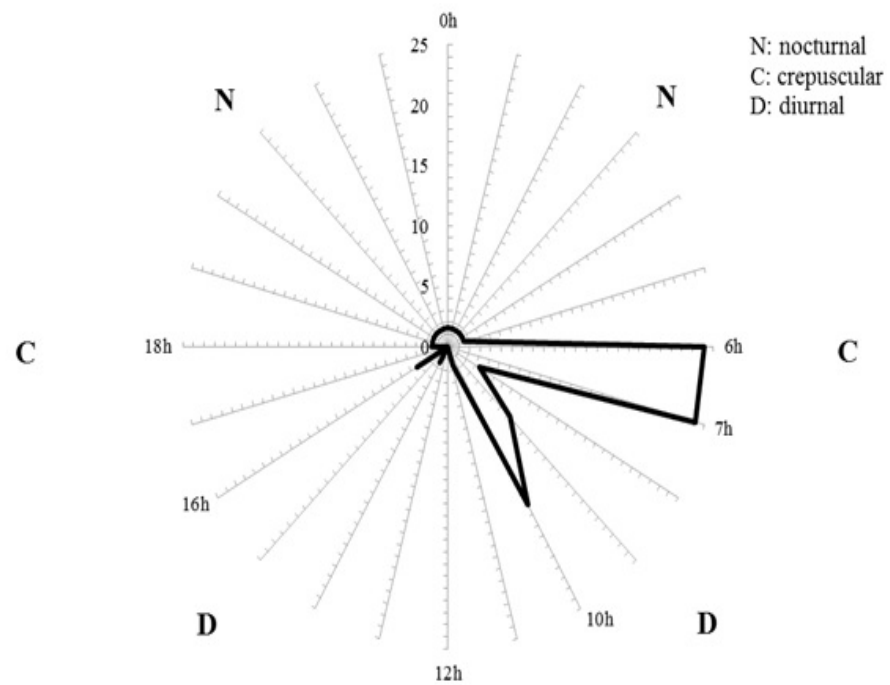

Figure 1. Andean bears scavenging time patterns between 2013-2015 in Chingaza National Natural Park and buffer zones, Colombia. Distance from the centroid indicates the frequency of records according to 1 - hour intervals. 
On October 27, 2014 and individual was recorded scavenging on a cow carcass between 10:50 and 11:00 h in Chatasuga locality, Choachi municipality $\left(4^{\circ} 35^{\prime} 46.79^{\prime \prime} \mathrm{N},-73^{\circ}\right.$ $50^{\prime} 42.85^{\prime \prime} \mathrm{W}: 3,187$ masl); the individual was an adult, clearly identified by a small spot in the head and a long chest patch (Figure 2a). Three days after, the same individual was again photographed (October 30, 2014), but this time with two additional individuals, all scavenging simultaneously on the same carcass; all individuals were identified as adults according to their size and the previous photographs of the identified individual (Figure 2b). No antagonistic or aggressive behaviors were recorded between the individuals during the scavenging activity.

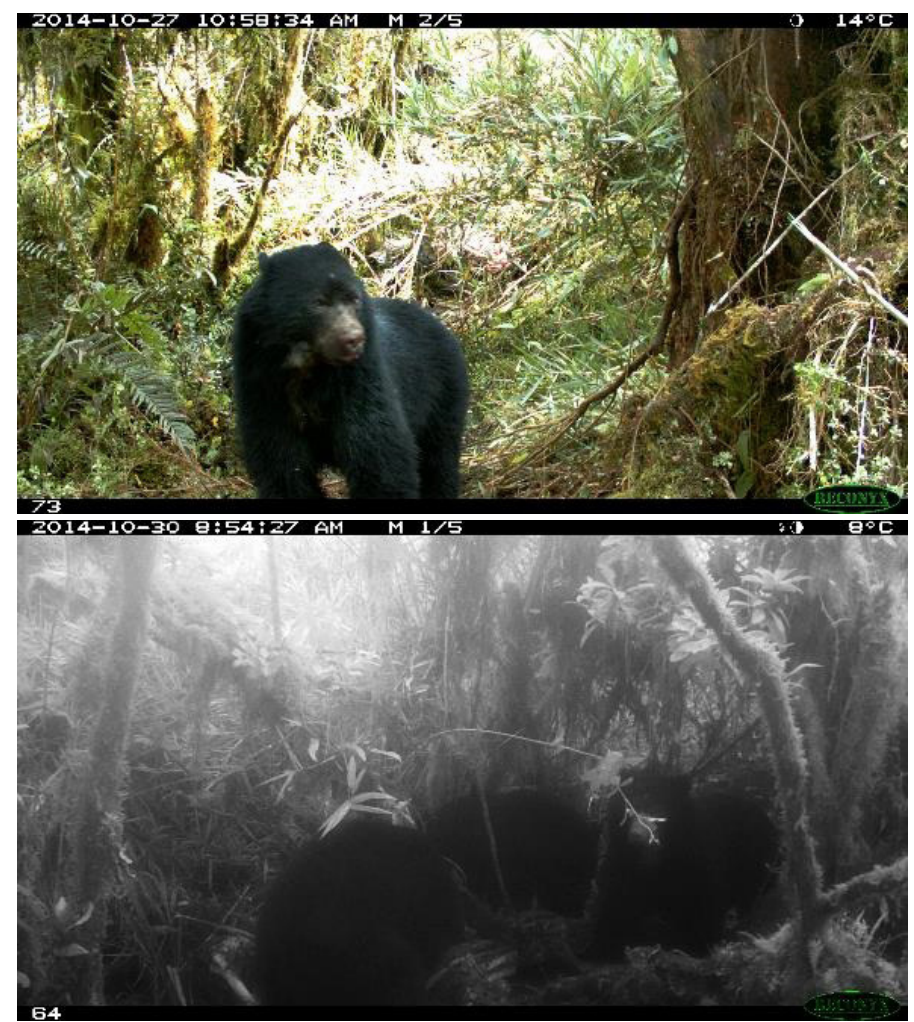

Figure 2. A) Individual Andean bear recorded on October 27, 2014 in Choach;í municipallity, Colombia. B) Group of Andean bears scavenging on a single carcass on October 30, 2014, at Choachí municipality, Chingaza National Natural Park, Colombia. From right to left the first individual was recorded feeding alone from the same carcass three days before.

\section{Discussion}

Activity patterns related with scavenging behaviors described herein coincide with the time activity patterns described for the species along its distribution (Paisley and Garshelis 2006, Rodríguez et al. 2016), being more active during the day, with two major activity peaks (morning and evening; Paisley 2001, García-Rangel 2012). Our data showed that Andean bears were scavenging mostly during morning hours (6:00 to 7:00 $\mathrm{h}$ and 9:00 to 10:00 h), with almost no scavenging activity during evening (16:00 h). This can be related with the activity pattern of the species, where activity starts around $6: 00 \mathrm{~h}$ and drops progressively along the day (Castellanos et al. 2005).

Despite the species is commonly classified as predomi- nantly herbivore (García-Rangel 2012), it seems animal protein can also constitute a significant component of its diet (Paisley 2001; Gonzales et al. 2016). Animal protein can therefore be obtained from wild and domestic animals by active hunting and scavenging. Recent studies have recorded active predation on a wide variety of wild prey from rodents to large species such as Mountain tapirs (Tapirus pinchaque) and White tail deer (Odocoileus virginianus; Horn et al. 2014; Rodriguez et al. 2014; Gonzales et al. 2016). Our results showed only one case of active predation behaviors, were the Ch-NNP rangers recorded a juvenile Andean bear actively chasing a newborn cow. For the remaining records, local ranchers claimed Andean bears as potential predators, but we only found evidence of scavenging on carcasses.

Generally, predation/scavenging events of bears over cattle are usually categorized as conflicts and is currently considered the main cause of Andean bear illegal hunting across most of its distribution (Peyton et al. 1998; García-Rangel 2012); no surprise, most of these events are recorded in extensive cattle areas adjacent to protected areas (Figueroa 2015). In most areas, inadequate management of domestic species has contributed to the loss and transformation of natural ecosystems, which together with the introduction of exotic species (e. g., feral dogs, cows and cats), has led to changes in the typical time patterns and behaviors of Andean bears and other carnivore species in the tropical Andes (Zapata-Ríos and Branch 2016; Zapata-Rios and Branch 2018), as supported in our data from adjacent areas of Ch-NNP. Furthermore, two types of predation events have been commonly recorded: local reports of bears feeding from dead domestic animals, usually mis-attributing the predation to the Andean bear but with not confirmed evidence (Goldstein et al. 2006), and direct observations of Andean bears actively hunting domestic animals (Figueroa 2015), all resulting in Human-Andean bear conflicts, as also documented for our study area.

Documented social interactions are mostly unknown for the species and very scarce in the literature, with some observations only described from Peru, and for mating couples and family groups (Figueroa 2015). Andean bear adults are considered in general to be mostly solitary, and couples are only documented during the breeding season (García-Rangel 2012); however, social behaviors have been previously recorded with groups foraging on corn crops (Figueroa 2015). Other bear species commonly show these types of behaviors such Ursus arctos foraging for salmons (Quinn and Buck 2000). Social behaviors, such as the one recorded in this paper, have only been recorded in Bolivia (Paisley 2001) and this is the first description of this behavior in Colombia.

Based on our estimations, and validated by a group of experts, the three individuals scavenging in group were confidently identified as adults, however, it is impossible to certainly ensure if they belong or not to the same family group. Nevertheless, one of the three individuals (i. e., the 
individual with the spot in the forehead) was recorded foraging alone in other areas close to the carcass during the following days after the scavenging event reported, which allows for a more precise estimation of the adulthood of the individual. Nonetheless, according to Paisley (2001), eventually Andean bears conform rudimentary social groups when food availability is concentrated. Based on this record, multiple individuals could benefit from a scarce but yet likely significant resource, considering its size and the energy required for surviving in this type of ecosystems.

Most aspects of Andean bear natural history, and especially behavior, are still unknown across most of its distribution (Castellanos et al. 2005, Vela-Vargas et al. 2011) and specially in Colombia. To our knowledge, this is the first record of potential group, none-antagonistic, scavenging behavior for Andean bear and the first report of scavenging activity and time patterns for the species in Colombia. Knowledge on natural history of the species will likely better inform conservation strategies, especially for conflict mitigation, and thus we urge to not only keep documenting records of the species but to make valuable information available for its appropriate use for research and decisionmaking.

\section{Acknowledgements}

We want to thank all the park rangers at Ch-NNP, especially to Elias Raigoso, Arnulfo Pérez, Oscar Raigozo, Luis Linares, Germán Parra, and also the community of Chatasugá locality at the Choachí municipality, for their efforts and collaboration with Andean bear conservation. We would like to thank Elias Raigozo and Robert Marquez for their help estimating the age of the individuals in our records. Thanks to two anonym referees for their valuable comments to the manuscript. This paper was developed as part of agreement 003 of 2016 between ProCAT Colombia and Parques Nacionales Naturales de Colombia - Dirección Territorial Orinoquía.

\section{Literature Cited}

Armenteras, D., F. Gast, and H. Villareal. 2003. Andean forest fragmentation and the representativeness of protected natural areas in the eastern Andes, Colombia. Biological Conservation 113:245-256.

Cáceres-Martínez, C. H., A. Acevedo, and J. F. González-Maya. 2016. Terrestrial medium and large sized mammal's diversity and activity patterns from Tamá National Natural Park and buffer zone, Colombia. Therya 7:285-298.

Castaño-Uribe, C., J. F. Gonzalez-Maya, D. Zárrate-Charry, C. Ange-Jaramillo, and I. M. Vela-Vargas (eds.). 2013. Plan de Conservación de Felinos del Caribe colombiano: Los felinos y su papel en la planificación regional integral basada en especies clave. Conservación Internacional, Fundación Herencia Ambiental Caribe, The Sierra To Sea Institute ProCAT Colombia, Santa Marta, Colombia.

Castellanos, A. P., M. B. Altamirano, and G. A. Tapia. 2005. Ecología y comportamiento de osos Andinos reintroducidos en la reserva biológica Maquipucuna, Ecuador: implicaciones en la conservación. Revista Politécnica 26:54-82.

Di Bitettı, M. S., A. Paviolo, and C. De Angelo. 2006. Density, habitat use and activity patterns of ocelots (Leopardus pardalis) in the Atlantic forest of Misiones, Argentina. Journal of Zoology 270:153-163.

ELGMORK, K., AND E. TJORVE. 1995. Brown bear Ursus arctos scavenging patterns. Wildlife Biology 1:239-242.

FigueroA, J. 2015. Interacciones Humano - Oso Andino Tremarctos ornatus en el Perú: consumo de cultivos y depredación de ganado. Therya 6:251-278.

GarCíA-RANGEL, S. 2012. Andean bear Tremarctos ornatus natural history and conservation. Mammal Review 42:85-119.

Goldstein, I., S. Paisley, R. Wallace, J. P. Jorgenson, F. Cuesta, and A. CAStellanos. 2006. Andean bear - livestock conflicts: a review. Ursus 17:8-15.

Gonzales, F. N., J. Neira-Llerena, G. Llerena, and H. Zeballos. 2016. Small vertebrates in the spectacled bear's diet (Tremarctos ornatus Cuvier, 1825) in the north of Peru. Revista Peruana de Biología 23:61-66.

González-Maya, J. F., D. Zárrate-Charry, I. M. Vela-Vargas, J. S. Jiménez-Alvarado, AND D. Gómez-Hoyos. 2015. Activity patterns of Tayra Eira barbara populations from Costa Rica and Colombia: evidence of seasonal effects. Revista Biodiversidad Neotropical 5:96-104.

Horn, R. van, R. Appleton, and J. Amanzo. 2014. Andean bears in two peruvian forests are rarely photographed with meat. International Bear News 23:20-22.

JORGENSON, J. P., AND S, SANDOVAL. 2005. Andean bear management needs and interactions with humans in Colombia. Ursus 16: 108-116

Kattan, G., O. L. Hernández, I. Goldstein, V. Rojas, O. Murillo, C. Gómez, H Restrepo, AND F. CUeSTA. 2004. Range fragmentation in the spectacled bear Tremarctos ornatus in the northern Andes. Oryx 38:155-163.

MÁRQUEZ, R., AND I.GoldSTEIN. 2014. Manual para el reconocimiento y evaluación de eventos de depredación de ganado por carnívoros silvestres. Versión 1.0. Wildlife Conservation Society Colombia. Santiago de Cali, Colombia.

OreJuela, J., AND J. P. Jorgenson. 1999. Status and management of the spectacled bear in Colombia. Pp. 168-179 in Bears: status survey and conservation plan. IUCN/SSC Bear and Polar Bear Specialists Groups (Servheen, C., S. Herrero, and B. Peyton, eds). International Union for the Conservation of Nature and Natural Resources, Gland, Switzerland.

PaisLey, S. 2001. Andean bears and people in Apolobamba, Bolivia: Culture, conflict and conservation. Durell Institute of Conservation and Ecology. PhD thesis. Canterbury. England. Paisley, S., AND D. L. Garshelis. 2006. Activity patterns and time budgets of Andean bear (Tremarctos ornatus) in the Apolobamba range of Bolivia. Journal of Zoology 268:25-34. Parques Nacionales Naturales de Colombia. 2016. Reformulación participativa del plan de manejo Parque Nacional Natural Chingaza. Bogotá, Colombia.

Peyton, B., E. Yerena, D. I. Rumiz, J. P. Jorgenson, and J. Orejuela. 1998. Status of Wild Andean bears and Policies for their management. Ursus 10:87-100.

QUINN, T. P., AND G. B. Buck. 2000. Scavenging by brown bears, Ursus arctos, and Glaucous-winged Gulls, Larus glaucescens, 
on Adult Sockeye Salmon, Onocorhynchus nerka. Canadian Field-Naturalist 144:217-223.

R CORE TEAM. 2017. R: A language and environment for statistical computing. R Foundation for Statistical Computing. Vienna, Austria.

Rodriguez, A., R. Gomez, A. Moreno, C. Cuellar, and D. J. Lizcano. 2014. Record of a mountain tapir attacked by an Andean bear on a camera trap. Tapir Conservation 23:25-26.

Rodríguez, D., N. Reyes-Amaya, A. Reyes, H. Restrepo, Y. Casas, O. Salgado, J. Rodríguez, and H. Gómez. 2016 . Performance of a GPS collar tracking a spectacled bear (Tremarctos ornatus) in the Colombian Andes. Revista Biodiversidad Neotropical 6:68-76.

Troya, V., F. Cuesta, and M. Peralvo. 2004. Food habits of Andean bears in the Oyacachi River Basin, Ecuador. Ursus 15:57-60.

Vela-Vargas, I. M., G. Domínguez, J. Galindo, and J. Pérez-Torres. 2011. El Oso Andino sudamericano, su importancia y conservación. Ciencia 62:44-51.

Wilson, E. E., and E. M. Wolkovich. 2011. Scavenging: How carnivores and carrion structure communities. Trends in Ecology and Evolution 26: 129-135.

Zapata-Ríos, G., AND L. C. BRAnCH. 2016. Altered activity patterns and reduced abundance of native mammals in sites with feral dogs in the high Andes. Biological Conservation 193:9-16.

Zapata-Ríos, G., AND L. C BRANCH. 2018. Mammalian carnivore occupancy is inversely related to presence of domestic dogs in the high Andes of Ecuador. Plos One 13: e0192346: 1-17.

Associated editor: Jorge Servin

Submitted: Abril 30, 2018; Reviewed: Agosto 27, 2018;

Accepted: November 4, 2018; Published on line: November 15, 2018. 
ANDEAN BEAR SCAVENGING BEHAVIORS

54 THERYA Vol. 10 (1): 49-53 